PRECIADO-RANGEL, P; SALAS-PÉREZ, L; GALLEGOS-ROBLES, MA; RUIZ-ESPINOZA, FH; AYALA-GARAY, AV; FORTIS-HERNÁNDEZ, M; MURILLO-AMADOR, B. 2018. Increasing doses of potassium increases yield and quality of muskmelon fruits under greenhouse. Horticultura Brasileira 36: 184-188. DOI: http://dx.doi.org/10.1590/S0102-053620180206

\title{
Increasing doses of potassium increases yield and quality of muskmelon fruits under greenhouse
}

\author{
Pablo Preciado-Rangel ${ }^{1}$; Lilia Salas-Pérez²; Miguel Á Gallegos-Robles ${ }^{3}$; Francisco H Ruiz-Espinoza ${ }^{4}$; Alma \\ V Ayala-Garay5; Manuel Fortis-Hernández'; Bernardo Murillo-Amador ${ }^{6}$
}

${ }^{1}$ Instituto Tecnológico de Torreón, Coahuila, Mexico; ppreciador@yahoo.com.mx; fortismanuel@hotmail.com; ${ }^{2}$ Universidad Politécnica de Gómez Palacio, Torreón, Mexico; lilia-nt@hotmail.com; ${ }^{3}$ Universidad Juárez del Estado de Durango, Durango, Mexico; garoma64@hotmail. com; ${ }^{4}$ Universidad Autónoma de Baja California Sur, Baja California Sur, Mexico; fruiz@uabcs.mx; ${ }^{5}$ Instituto Nacional de Investigaciones Forestales, Agrícolas y Pecuarias, Texcoco, Mexico; ayala.alma@inifap.gob.mx; ${ }^{6}$ Centro de Investigaciones Biológicas del Noroeste, Baja California Sur, Mexico; bmurillo04@cibnor.mx; (autor para correspondencia)

\begin{abstract}
Potassium (K) influences the variables that determine quality of fruit and the concentration of phytonutrients to human health and therefore consumer preferences. The objective of this study was to evaluate the effect of different concentrations of $\mathrm{K}$ in the nutrient solution $(5,7,9$ and $11 \mathrm{mM}$ of $\mathrm{K})$ on yield and quality of Cantaloupe fruits under greenhouse conditions. The experiment was conducted in pots using a completely randomized design with 15 replications. Analysis of variance, correlation, regression and multiple comparisons among means (Tukey $\mathrm{p}<0.05$ ) were performed. Results showed higher values of yield, average fruit weight, equatorial diameter, pulp thickness, fruit firmness, soluble solids content, phenolic content and antioxidant capacity of fruits at the concentrations of 9 and $11 \mathrm{mM}$ of $\mathrm{K}$. All variables, except equatorial diameter, increased their values as $\mathrm{K}$ concentrations increased, showing a lineal, positive and significant trend, which evidences that the optimal dose of $\mathrm{K}$ in muskmelon is higher than $11 \mathrm{mM}$, being suggested for future research, to evaluate concentrations above this value.
\end{abstract}

Keywords: Cucumis melo, plant nutrition, nutraceutical quality.

\section{RESUMO}

Incremento de doses de potássio favorece a produtividade e qualidade de melão em casa de vegetação

O potássio $(\mathrm{K})$ influencia as variáveis que determinam a qualidade dos frutos e a concentração de fitonutriente para a saúde humana e, portanto, as preferencias do consumidor. O objetivo desse estudo foi avaliar o efeito de diversas concentrações de $\mathrm{K}$ na solução nutritiva $(5,7,9$ e $11 \mathrm{mM}$ de $\mathrm{K})$ sobre o rendimento e qualidade de frutos de melão Cantaloupe em casa de vegetação. $\mathrm{O}$ experimento foi realizado em vasos, em delineamento experimental completamente casualizado, com 15 repetições. Foram analisadas a variância, correlação, regressão e comparação múltipla de médias (Tukey p $<0,05$ ). Obtiveram-se valores maiores de produtividade, peso médio de frutos, diâmetro equatorial, espessura da polpa, firmeza da polpa, teor de sólidos solúveis totais, teor de compostos fenólicos e capacidade antioxidante dos frutos nas concentrações de 9 e $11 \mathrm{mM}$ de K. Todas variáveis, com exceção de diâmetro polar dos frutos, tiveram seus valores aumentados, com concentrações crescentes de K, evidenciando tendência linear positiva e significativa, indicando que a dose ótima de $\mathrm{K}$ em melão é superior a $11 \mathrm{mM}$. Assim, sugere-se para pesquisas futuras, avaliar concentrações acima de $11 \mathrm{mM}$..

Palavras chave: Cucumis melo, nutricão vegetal, qualidade nutracêutica.

Received on November 9, 2016; accepted on December 10, 2017

$\mathrm{T}$ he Cucurbitaceae family, which includes cucumbers, pumpkins, muskmelons, squash and pumpkins, consists of hundreds of wild and cultivated varieties. Of these, muskmelon (Cucumis melo) is an important horticultural crop in arid and semi-arid regions, due to its good adaptation to the soil and climatic conditions (Kusvuran et al., 2012), with a total annual production of 31.92 million tons (FAOSTAT, 2014).

However, production under field conditions focuses in a few weeks, mainly due to climatic factors, then, to extend the availability of this product in the market, it is necessary to use other production methods (Arellano et al., 2011).

In this situation, horticultural production under protected systems is an alternative to traditional field production, especially in highly profitable crops (Pardossi et al., 2002). The development of muskmelon plants under greenhouse conditions compared to those developed in field, have many advantages such as precocity, yield increases and water use and fertilizer efficiency (PreciadoRangel et al., 2011).

The low restrictive environment and the increase of fertilization especially nitrogen, allows high yields (PreciadoRangel et al., 2011); however, this decreases the nutraceutical quality, because of when there is no deficit of nitrogen $(\mathrm{N})$ the production of compounds such as amino acids, proteins, and alkaloids that contain $\mathrm{N}$ increased (Hallmann \& Rembiałkowska, 2012). Therefore, researches of the factors that enhance the nutraceutical 
content of fruit were promoted (Navarro et al., 2006). In particular, total phenols have a high antioxidant capacity, highly desirable nutraceutical characteristic that can contribute to improved health (Fischer et al., 2013; Rinaldi et al., 2013). Therefore, a high content of phenols and antioxidants, allow greater competitiveness in domestic and international markets; however, studies using different $\mathrm{K}$ concentrations in the nutrient solution and quality of muskmelon were not found.

Muskmelon has low fat and sodium (Na) content, no cholesterol and provides many essential nutrients such as potassium $(\mathrm{K})$, besides being a rich source of beta-carotene and vitamin $\mathrm{C}$. The factors that may affect quality of fruits include genotype, environmental conditions and fertilization (Beckles, 2012).

Regarding fertilization, in recent years, to improve nutritional and nutraceutical quality of vegetable products for human consumption, the bio-fortification programs consisting of cultivation of species to increase their nutritional value, include trace elements such as micronutrients (Montoya et al., 2013; Constán-Aguilar et al., 2014).

Concerning macronutrients, $\mathrm{K}$ is the one that exerts greater influence on the characteristics that determine the consumer's preferences, the quality of the fruits and the concentration of phytonutrients of vital importance to human health (Lester et al., 2010).

Under this perspective, the objective of this study was to evaluate the effect of different concentrations of $\mathrm{K}$ in the nutrient solution applied during the growth period of muskmelon plants and their effect on yield and nutraceutical quality of fruits.

\section{MATERIAL AND METHODS}

\section{Study area}

The study was conducted under greenhouse conditions with automated control system of environmental conditions at Instituto Tecnológico of Torreón, México (253' $37^{\prime}$ N, $103^{\circ} 22^{\prime} 32$ "W, altitude $1123 \mathrm{~m}$ ). During the growing season, minimum and maximum temperatures inside greenhouse fluctuated between 20 and $35^{\circ} \mathrm{C}$, while the minimum and maximum relative humidity ranged from 60 to $80 \%$.

\section{Crop management}

Sowing was done directly, placing a seed of Expedition genotype (Harris Moran ${ }^{\circledR}$, USA) in black polyethylene bags of $20 \mathrm{~L}$, caliber 500 and nursery type, which were used as pots and placed in an arrangement called "quincunx". Density was of six plants per square meter leaving one fruit per plant. Prewashed and sterilized river sand with a solution of $5 \%$ of $\mathrm{NaClO}$ was used as substrate. The treatments were designed from modifications of the Steiner nutrient solution and consisted of increasing levels of $\mathrm{K}(5,7,9$ and 11 $\mathrm{mM})$. Each treatment consisted of one plant/pot, distributed in a completely randomized design with 15 replications (one pot per replication). All nutrient solutions contained (in $\mathrm{mM} \mathrm{L}^{-1}$ ) $8 \mathrm{Fe}$, $0.865 \mathrm{~B}, 1.6 \mathrm{Mn}, 0.023 \mathrm{Zn}, 0.11 \mathrm{Cu}$ and $0.5 \mathrm{Mo}$ and were adjusted to an osmotic potential of $-0.073 \mathrm{MPa}$ and $\mathrm{pH}$ of 5.5. The nutrient solutions were formulated using high soluble commercial fertilizers, available in the local market. Three irrigations were applied daily, using a drip irrigation system, whose volume ranged from $0.750 \mathrm{~L} \mathrm{pot}^{-1}$ from sowing to the beginning of flowering (45 days after sowing) and $2.0 \mathrm{~L}$ plant $^{-1}$ were provided from flowering to harvesting stage, which began 85 days after sowing. Plants were pruned to a stem and subsequently supported with stakes which were placed using raffia thread, holding one extreme on the stem base and the other to a metal wire which was secured to the firm structure of the greenhouse. Bees were used to pollinate flowers, introducing them to the greenhouse during the flowering stage. Several fruits were set after pollination with bees; however, only one fruit per plant was left. After pollination, fruits were pruned and the biggest one selected, which remained on plant until harvest. Harvest took place when the fruits break of from peduncle.

Fruit average weight and quality

Fruits were harvested at full slip phase, when stem was completely separated. The fruit average weight was expressed in kilograms per plant.

Fruit size (polar and equatorial diameter in $\mathrm{cm}$ ), pulp thickness $(\mathrm{cm})$, total soluble solids in Brix grades ( ${ }^{\circ}$ Brix) were measured on each harvested fruit. Brix grades were determined with a hand refractometer with scale from 0 to $32 \%$ (Atago ${ }^{\circledR}$ Master 2311), on each harvested fruit. Fruit pulp firmness was measured using a penetrometer $\left(\right.$ Extech $^{\circledR}$, FHT200) placing a plunger of $8-\mathrm{mm}$ diameter and a $2-\mathrm{cm}^{2}$ portion that was removed from the skin on opposite sides of fruit, averaging the two measurements in Newtons (N). Phenols content was quantified according to the methodology of Esparza-Rivera et al. (2006) and antioxidant capacity by the method of Brand-Williams et al. (1995).

\section{Statistical analysis}

Analysis of variance and multiple comparisons (Tukey HSD, $\mathrm{p}<0.05$ ) were performed. All analyses were executed using SAS statistical software v. 9.0. Pearson correlation analysis $(\mathrm{p}<0.05)$ and simple linear regression were performed considering as independent variable the $\mathrm{K}$ concentrations.

\section{RESULTS AND DISCUSSION}

\section{Fruit average weight and quality}

The results of this study indicate that concentrations of $\mathrm{K}$ in the nutrient solutions significantly influenced the fruit average weight $(p<0.05$, Table 1$)$; obtaining the greatest yield those plants treated with the highest concentrations of $\mathrm{K}$. These results were expected because $\mathrm{K}$ plays a vital role in the filling of fruits. There is an increase in requirement for $\mathrm{K}$ during the plant's production process; so, when the muskmelon plants of this experiment received enough $\mathrm{K}$, the efficiency of water was improved by increasing osmotic pressure of cells, making them more turgid and increasing the weight and size of fruits.

The report of Tuna et al. (2010) indicate an increase in muskmelons fruit average weight with high concentrations of $\mathrm{K}$, corroborating results of current study, due to the deficiency or excess of this macroelement limiting growth and crop yield (Tang et al., 2012; Hafsi 
et al., 2014). However, there is no dose or unique concentration because of differences found in yield, due to different varieties, soil and weather conditions, crop management (Silva-Dias et al., 2005), source and method of fertilizers application (Lester et al., 2010). Fruit weight showed significant and positive correlation with concentration of $\mathrm{K}$ in the nutrient solution; this means that, fruit weight increases with increasing $\mathrm{K}$ concentrations (Table 2). This correlation occurred due to the fact that this element plays a fundamental function in the filling of fruits, promoting greater firmness and resistance of the tissues since potassium is absorbed in large quantities in crops such as muskmelon. Similar results reported Demiral \& Köseoğlu (2005).

The fruit polar diameter did not show significant differences among concentrations of $\mathrm{K}$, however, the values varied from highest to lowest as follows:
9>11>7>5 mM of K (Table 1). Although $\mathrm{K}$ increases the weight and size of the fruits, the increase of fruit polar diameter was slight with only $4.44 \%$ in $9 \mathrm{mM}$ compared to $5 \mathrm{mM}$ of $\mathrm{K}$. The fruit equatorial diameter showed significant differences among the concentrations of K (Table 1) and varied from highest to lowest as follows: $11>9>(7=5)$. Polar diameter was equal at 7 and $5 \mathrm{mM}$ of $\mathrm{K}$. The fruit equatorial diameter increased $9.10 \%$ at $11 \mathrm{mM}$ compared to 7 and 5 $\mathrm{mM}$ of $\mathrm{K}$. The fruit polar and equatorial diameters were greatest in those plants treated with concentrations of 9 and 11 $\mathrm{mM}$ of $\mathrm{K}$, respectively. The fruits size in our study was similar to those reported by Moreno-Resendez et al. (2010).

The fruit equatorial diameter showed a significant and positive correlation with the concentration of $\mathrm{K}$ and increased as the concentration of $\mathrm{K}$ increased (Table 2); nevertheless, correlation among fruit polar diameter and $\mathrm{K}$ concentration was not significant. The fruit yield achieved in those plants treated with $11 \mathrm{mM}$ of $\mathrm{K}$, exceeds $41 \%$ of those obtained in field (Camberos \& Rios, 2000). This result confirms that under protected conditions and using nutrient solutions, the fruit average weight increases. The results of present study are consistent with Preciado-Rangel et al. (2002) who reported that some muskmelon hybrids, showed greatest demand of $\mathrm{K}$ and that the different hybrids require different nutritional conditions to show their full potential.

Fruit pulp thickness showed significant differences among the different concentrations of $\mathrm{K}$ getting the greatest values in those plants treated with 9 and $11 \mathrm{mM}$ of K (Table 1). Fruit pulp thickness showed significant and positive correlation with the concentration of $\mathrm{K}$ in the nutrient solution, displaying a linear relationship, because of, increasing K concentrations

Table 1. Effect of potassium $(\mathrm{K})$ concentrations in the nutrient solution, on fruit average weight, polar and equatorial diameter, pulp thickness, total soluble solids, firmness, phenols content and antioxidant capacity of muskmelon fruits. Mexico, Instituto Tecnológico de Torreón, 2015.

\begin{tabular}{|c|c|c|c|c|c|c|c|c|}
\hline \multirow{2}{*}{$\mathbf{K}(\mathbf{m} \mathbf{M})$} & \multirow{2}{*}{$\begin{array}{c}\text { Fruit average } \\
\text { weight (kg) }\end{array}$} & \multicolumn{2}{|c|}{ Diameter $(\mathbf{c m})$} & \multirow{2}{*}{$\begin{array}{l}\text { Pulp } \\
\text { thickness (cm) }\end{array}$} & \multirow{2}{*}{$\begin{array}{c}\text { Firmness } \\
\text { (N) }\end{array}$} & \multirow{2}{*}{$\begin{array}{c}\text { TSS } \\
\left({ }^{\circ} \text { Brix) }\right.\end{array}$} & \multirow{2}{*}{$\begin{array}{l}\text { Phenols content (mg } \\
\text { equivalent Gallic acid } \\
\left.\quad 100 \mathrm{~g} \mathrm{FB}^{-1}\right)\end{array}$} & \multirow{2}{*}{$\begin{array}{c}\text { Antioxidant capacity } \\
(\mu \mathrm{M} \text { equiv } \\
\text { Trolox } / 100 \mathrm{~g} \text { FB })\end{array}$} \\
\hline & & Polar & Equatorial & & & & & \\
\hline 5 & $1.01 \mathrm{~b}$ & 13.50 & $11.10 \mathrm{~b}$ & $2.95 \mathrm{~b}$ & $18.11 \mathrm{~b}$ & $11.90 \mathrm{~b}$ & $31.46 \mathrm{~b}$ & $114.90 \mathrm{c}$ \\
\hline 7 & $0.95 \mathrm{~b}$ & 13.51 & $11.10 \mathrm{~b}$ & $2.95 \mathrm{~b}$ & $18.58 \mathrm{~b}$ & $11.90 \mathrm{~b}$ & $30.79 \mathrm{~b}$ & $162.90 \mathrm{~b}$ \\
\hline 9 & $1.11 \mathrm{a}$ & 14.10 & $11.70 \mathrm{ab}$ & $3.45 \mathrm{a}$ & $20.88 \mathrm{~b}$ & $12.20 \mathrm{ab}$ & $33.22 \mathrm{~b}$ & $191.40 \mathrm{ab}$ \\
\hline 11 & $1.12 \mathrm{a}$ & 13.64 & $12.11 \mathrm{a}$ & $3.12 \mathrm{ab}$ & $23.92 \mathrm{a}$ & $12.70 \mathrm{a}$ & $39.27 \mathrm{a}$ & $213.10 \mathrm{a}$ \\
\hline CV (\%) & 4.66 & 3.46 & 3.84 & 6.70 & 4.45 & 2.87 & 7.79 & 8.95 \\
\hline
\end{tabular}

${ }^{1}$ Data expressed as $\mu \mathrm{M}$ equivalent in Trolox per $100 \mathrm{~g}$. FB $=$ fresh base. Values in each column followed by the same letter(s) are not significantly different at $\mathrm{p} \leq 0,05$ (Tukey HSD). TSS $=$ total soluble solids. $\mathrm{N}=$ Newtons.

Table 2. Correlation coefficient (Pearson), determination coefficient and simple linear regression equation among potassium concentrations $(\mathrm{mM})$ and dependent variables, phenols content, antioxidant capacity, yield, fresh weight, equatorial diameter, pulp thickness, total soluble solids and firmness of muskmelon fruits. Mexico, Instituto Tecnológico de Torreón, 2015.

\begin{tabular}{lccc}
\hline Dependent variables & $\begin{array}{c}\text { Correlation } \\
\text { coefficient }(\mathbf{r})\end{array}$ & $\begin{array}{c}\text { Determination } \\
\text { coefficient }\left(\mathbf{R}^{2}\right)\end{array}$ & $\begin{array}{c}\text { Simple linear regression } \\
\text { equation }\end{array}$ \\
\hline Phenols content & $0.72^{* *}$ & 0.52 & $\mathrm{PC}=23.34+1.29 \times \mathrm{K}^{* *}$ \\
Antioxidant capacity & $0.93^{* * *}$ & 0.86 & $\mathrm{AC}=41.49+16.14 \times \mathrm{K}^{* * *}$ \\
Fresh weight & $0.63^{* *}$ & 0.39 & $\mathrm{FW}=0.89+0.02 \times \mathrm{K}^{* *}$ \\
Yield & $0.67^{* * *}$ & 0.46 & $\mathrm{Y}=5.30+0.13 \times \mathrm{K}^{* * *}$ \\
Equatorial diameter & $0.59^{* *}$ & 0.34 & $\mathrm{ED}=10.41+0.14 \times \mathrm{K}^{* *}$ \\
Pulp thickness & $0.62^{* *}$ & 0.38 & $\mathrm{PT}=2.49+0.08 \times \mathrm{K}^{* *}$ \\
Total soluble solids & $0.67^{* * *}$ & 0.45 & $\mathrm{TSS}=11.06+0.13 \times \mathrm{K}^{* * *}$ \\
Firmness & $0.90^{* * *}$ & 0.81 & $\mathrm{~F}=12.49+0.98 \times \mathrm{K}^{* * *}$ \\
\hline
\end{tabular}

Significance level $(\mathrm{p})=* * \mathrm{p}<0.01 ; * * * \mathrm{p}<0.001$. 
resulted in fruit pulp thickness increase (Table 2). These results do not match with those reported by Silva et al. (2014) who found a quadratic response for fruit pulp thickness and a linear trend in the fruit size caused by increased fertilization with $\mathrm{K}$.

Pulp firmness showed significant differences between $\mathrm{K}$ concentrations, exhibiting greatest value in the concentration of $11 \mathrm{mM}$ of $\mathrm{K}$ (Table 1). Pulp firmness showed significant and positive correlation with the concentration of $\mathrm{K}$ in the nutrient solution, increasing as the concentration of $\mathrm{K}$ increased (Table 2). Also, fruit firmness showed significant and positive correlation with total soluble solids content, because of, as fruit firmness increases, total soluble solids content also increase. In this regard, Lester et al. (2010) indicate that fruit firmness is correlated with the pressure potential ( $\psi \mathrm{p}$ ) because $\mathrm{K}$ increases the accumulation of sugars (solutes) in fruits (Ribas et al., 2003). Similarly, Demiral \& Köseoğlu (2005) reported this positive relationship among fruit firmness and total soluble solids. From the commercial viewpoint, when fruit firmness increases, acceptance of the muskmelon fruits by the consumer is improved, because they prefer fruits with firm pulp instead of soft and watery (Ribas et al., 2003) being 23.6 Newtons the optimal value for fruit firmness in muskmelon (Silva-Dias et al., 2005).

Potassium concentrations in the nutrient solution, stimulated significant differences $(p<0.05$; Table 1$)$ in the soluble solids content, getting the greatest values those fruits from plants treated with $11 \mathrm{mM}$ of $\mathrm{K}$, validating the positive effect of $\mathrm{K}$ on fruit quality (Demiral \& Koseoglu, 2005; Tang et al., 2012; Silva et al., 2014). Furthermore, the content of total soluble solids showed significant and positive correlation with the concentration of $\mathrm{K}$ in the nutrient solution, revealing a linear relationship caused of increasing $\mathrm{K}$ concentrations, also the content of total soluble solids increased (Table 2).

The concentration of soluble solids of fruits harvested from plants treated with the concentrations of $\mathrm{K}$ exceeded the minimum value $\left(9^{\circ}\right.$ Brix) (Table 1$)$ reported as acceptable in market (Mata \& Mendez, 2009). This confirms that transport of sugars to fruits was effective since $\mathrm{K}$ has an important role in the transport of solutes through phloem (White \& Karley, 2010) and these fruits are considered marketable because total soluble solids are one of the main quality criteria for muskmelon fruits (Budiastuti et al., 2012).

The results showed that the increase of $\mathrm{K}$ concentration, exhibited an increase in phenols content and antioxidant capacity, both characteristics showed greatest values in the concentration of $11 \mathrm{mM}$ of $\mathrm{K}(\mathrm{p}<0.05$, Table 1$)$; which is an advantage since the fruits with greatest phytonutrients content have great interest because their consumption is associated with a lower risk of cardiovascular diseases and certain cancers types (Llacuna \& Mach, 2012). The antioxidant compounds are essential in the nutritional quality of fruits and are rated an essential factor in determining their price in the market (Frusciante et al., 2007). Lester et al. (2010) found that muskmelon fruits from plants treated with different sources of $\mathrm{K}$ had greatest content of antioxidants compared with untreated fruits.

The beneficial effects of K supplement to the plant were presumably result of a combination of an improvement in the assimilation of $\mathrm{CO}_{2}$, higher photosynthetic activity and greatest translocation of photoassimilates from leaves to fruits, improved water relations, greater enzyme activity and substrate availability for the biosynthesis of bioactive compounds; so the amount of antioxidants of a plant is also a good indicator of stress tolerance (Kusvuran et al., 2012).

Phenols content and antioxidant capacity showed significant and positive correlation with the concentration of $\mathrm{K}$ in the nutrient solution, with a linear relationship caused by the concentration of $\mathrm{K}$ increased in the nutrient solution; the values of both variables also increased (Table 2), demonstrating that $\mathrm{K}$ contributes significantly to the antioxidant capacity and phenols content in muskmelon fruits. The current study demonstrated that the concentrations of 9 and $11 \mathrm{mM}$ of $\mathrm{K}$ positively influenced the increased yield and fruit quality of muskmelon. The best concentration to maximize yield and quality of muskmelon fruits was $11 \mathrm{mM}$ of $\mathrm{K}$. Given the linear trend of all characteristics (except fruit polar diameter) to increase their values as concentrations of $\mathrm{K}$ increased, it evidences that the optimal dose of $\mathrm{K}$ in muskmelon is greater than $11 \mathrm{mM}$, suggesting, for future research, to evaluate concentrations of $\mathrm{K}$ above 11 $\mathrm{mM}$.

\section{ACKNOWLEDGEMENTS}

Thanks to Lidia Hirales-Lucero, Pedro Luna-García and Manuel Salvador Trasviña-Castro for technical support. Diana Dorantes-Fischer for English edition is gratefully acknowledged. The corresponding author is grateful to Consejo Nacional de Ciencia y Tecnología (Mexico) by supporting the modality of sabbatical stays abroad within the framework of the national call support for sabbatical stays related to the consolidation of research groups and/or strengthening of the national postgraduate program (2017-I).

\section{REFERENCES}

ARELLANO, JDJE; COTA, ML; NÁJERA, SL. 2011. Posibilidades y restricciones para la exportación de melón cantaloupe producido en el Municipio de Mapimí, Durango, México al mercado de los Estados Unidos. Revista Mexicana de Agronegocios 15: 593-604.

BECKLES, DM. 2012. Factors affecting the postharvest soluble solids and sugar content of tomato (Solanum lycopersicum L.) fruit. Postharvest Biology Technology 63: 129-140.

BRAND-WILLIAMS, W; CUVELIER, ME; BERSET, C. 1995. Use of a free radical method to evaluate antioxidant activity. Lebenmittel-Wissenschaft und Technologie 28:25-30.

BUDIASTUTI, S; PURNOMO, D; SULISTYO, TD; RAHARDJO, SP; DARSONO, L; PARDJO, V. 2012. The enhancement of melon fruit quality by application of the fertilizer and gibberellin. Journal of Agricultural Science and Technology 2: 455-460.

CAMBEROS, UN; RÍOS, PC. 2000. Umbral económico para la mosquita blanca de la hoja plateada en melón en la Comarca Lagunera, México. Agrociencia 34: 227-234.

CONSTÁN-AGUILAR, C; LEYVA, R; BLASCO, B; SÁNCHEZ-RODRÍGUEZ, E; SORIANO, 
T; RUIZ, JM. 2014. Biofortification with potassium: antioxidant responses during postharvest of cherry tomato fruits in cold storage. Acta Physiologiae Plantarum 36: 283-293

DEMIRAL, MA; KÖSEOGLU, AT. 2005. Effect of potassium on yield, fruit quality, and chemical composition of greenhouse-grown galia melon. Journal of Plant Nutrition 28: 93-100.

ESPARZA-RIVERA，JR; STONE, MB; STUSHNOFF, C; PILON-SMITS, E; KENDALL, PA. 2006. Effects of ascorbic acid applied by two hydro cooling methods on physical and chemical properties of green leaf lettuce stored at $5^{\circ} \mathrm{C}$. Journal of Food Science 71: $270-276$

FAOSTAT. 2014. Web site database. Available at http://faostat3.fao.org/faostat-gateway/go/to/ browse/rankings/commodities_by_regions/S

FISCHER, UA; JAKSCH, AV; CARLE, R; KAMMERER, DR. 2013. Influence of origin source, different fruit tissue and juice extraction methods on anthocyanin, phenolic acid, hydrolysable tannin and isolariciresinol contents of pomegranate (Punica granatum L.) fruits and juices. European Food Research and Technology 237: 209-221.

FRUSCIANTE, L; CARLI, P; ERCOLANO, MR; PERNICE, R; DI MATTEO, A; FOGLIANO, V; PELLEGRINI, N. 2007. Antioxidant nutritional quality of tomato. Molecular Nutrition Food Research 51: 609-617.

HAFSI, C; DEBEZ, A; ABDELLY, C. 2014. Potassium deficiency in plants: effects and signaling cascades. Acta Physiologiae Plantarum 36: 1055-1070.

HALLMANN, E; REMBIAŁKOWSKA, E. 2012. Characterization of antioxidant compounds in sweet bell pepper (Capsicum annuum L.) under organic and conventional growing systems. Journal of the Science of Food and Agriculture 92: 2409-2415.

KUSVURAN, S; ELLIALTIOGLU, S; YASAR, F; ABAK, K. 2012. Antioxidative enzyme activities in the leaves and callus tissues of salt-tolerant and salt-susceptible melon varieties under salinity. African Journal of Biotechnology 11: 635-641.

LESTER, GE; JIFON, JL; MAKUS, DJ. 2010. Impact of potassium nutrition on postharvest fruit quality: Melon (Cucumis melo L.) case study. Plant and Soil 335: 117-131.

LLACUNA, L; MACH, N. 2012. Papel de los antioxidantes en la prevención del cáncer. Revista Española de Nutrición Humana y Dietética 16: 16-24.

MATA, NM; MÉNDEZ, NJR. 2009. Efecto de reguladores de crecimiento sobre el epicarpo, mesocarpo y sólidos solubles totales del fruto de melón (Cucumis melo L.) cv. Edisto 47. Revista Cientifica UDO Agrícola 9: 295-303.

MONTOYA, S; ORTEGA, E; NAVARRO, E; LORENZO, M. 2013. Cucumber biofortification whith potassium. European Scientific Journal 9: 101-108.

MORENO-RESÉNDEZ, A; MEZA-MORALES, H; RODRÍGUEZ-DIMAS, N; REYESCARRILLO, JL. 2010. Development of muskmelon with different mixtures of vermicompost: sand under greenhouse conditions. Journal of Plant Nutrition 33: 1672-1680.

NAVARRO, JM; FLORES, P; GARRIDO, C; MARTINEZ, V. 2006. Changes in the contents of antioxidant compounds in pepper fruits at different ripening stages, as affected by salinity. Food Chemistry 96: 66-73.

PARDOSSI, A; MALORGIO, F; INCROCCI, L; CAMPIOTTI, CA; TOGNONI, F. 2002. A comparison between two methods to control nutrient delivery to greenhouse melons grown in recirculating nutrient solution culture. Scientia Horticulturae 92: 89-95.

PRECIADO-RANGEL, P; BACA-CASTILLO, GA; TIRADO-TORRES, JL; KOHASHISHIBATA, J; TIJERINA-CHAVEZ, L; MARTÍNEZ-GARZA, A. 2002. Nitrógeno y potasio en la producción de plántulas de melón. Terra Latinoamericana 20: 267-276.

PRECIADO-RANGEL, P; HERNÁNDEZ, MF; GARCÍA-HERNÁNDEZ, JL; RUEDA-
PUENTE, EO; RIVERA, JRE; HERRERA, AL; CASTRUITA, MAS; VIDAL, JO. 2011. Evaluación de soluciones nutritivas orgánicas en la producción de tomate en invernadero. Interciencia 36:,689-693.

RIBAS, F; CABELLO, M; MORENO, M; MORENO, A; LÓPEZ-BELLIDO, L. 2003. Influencia del riego y de la aplicación de potasio en la producción del melón (Cucumis melo L.). II: Calidad. Spanish Journal of Agricultural Research 1:,79-90.

RINALDI, M; CALIGIANI, A; BORGESE, R; PALLA, G; BARBANTI, D; MASSINI, R. 2013. The effect of fruit processing and enzymatic treatments on pomegranate juice composition, antioxidant activity and polyphenols content. Food Science and Technology 53: 355-359.

SILVA, MDC; DA SILVA, TJ; BONFIM-SILVA, EM; FARIAS, LDN. 2014. Características produtivas e qualitativas de melão rendilhado adubado com nitrogênio e potássio. Revista Brasileira de Engenharia Agrícola e Ambiental 18: 581-587.

SILVA-DIAS, N; DUARTE, SN; DE MEDEIROS, JF; VÁSQUEZ, MN. 2005. Calidad Postcosecha de frutos de melón producidos sobre diferentes niveles de salinidad del suelo y manejo de la fertirrigacion en invernadero. Ingenieria del Agua 12: 117.

TANG, M; ZHAO, H; BIE, Z; LI, Q; XIE, J; SHI, X; YI, H; SUN, Y. 2012. Effect of different potassium levels on growth and quality in two melon cultivars and two growing-seasons. Journal of Food Agriculture \& Enviroment 10: $570-575$.

TUNA, AL; KAYA, C; ASHRAF, M. 2010. Potassium sulfate improves water deficit tolerance in melon plants grown under glasshouse conditions. Journal of Plant Nutrition 33: 1276-1286.

WHITE PJ; KARLEY AJ. 2010. Cell biology of metals and nutrients. In: HELL, R; MENDEL, RR (eds). Potassium. Berlin/Heidelberg: Springer. p.199-224. 